\title{
Лапароскопічна холецистектомія із застосуванням субарахноїдальної анестезіі на спонтанному диханні
}

\author{
I. А. Криворучко ${ }^{1}$, Р. П. Чаплинський ${ }^{2}$ А. В. Вовк ${ }^{2}$, В. А. Вовк ${ }^{2}$, \\ Д. О. Смецков ${ }^{2}$, С. А. Андреєщев ${ }^{3}$ \\ ${ }^{1}$ Харківський національний медичний університет, \\ ${ }^{2}$ Харківська обласна клінічна лікарня, \\ ${ }_{3}^{3}$ Національна медична академія післядипломної освіти імені П. Л. Шупика, м. Київ
}

\section{Laparoscopic cholecystectomy, using subarachnoidal anesthesia in spontaneous respiration}

\section{A. Kryvoruchko ${ }^{1}$, R. P. Chaplynskyy ${ }^{2}$, A. V. Vovk ${ }^{2}$, V. A. Vovk ${ }^{2}$, D. O. Smetskov ${ }^{2}$, S. A. Andreyeshchev ${ }^{3}$}

${ }^{1}$ Kharkiv National Medical University,

${ }^{2}$ Kharkiv Regional Clinical Hospital, ${ }^{3}$

Shupyk National Medical Academy of Postgraduate Education, Kyiv

\section{Реферат}

Мета. Проаналізувати результати застосування субарахноїдальної анестезії на спонтанному диханні під час виконання лапароскопічної холецистектомії (ЛХЕ) для удосконалення методу регіонарної анестезії при операціях на органах черевної порожнини.

Матеріали і методи. У 549 пацієнтів, віднесених до I-III класу за класифікацією American Society of Anesthesiology (ASA), віком від 25 до 82 років, середній вік становив $(48,9 \pm 13,1)$ року, виконали ЛХЕ із пневмоперитонеумом, який створювали нагнітанням в черевну порожнину вуглекислого газу $\left(\mathrm{CO}_{2}\right)$, із застосуванням субарахноїдальної анестезії на спонтанному диханні. 3 приводу гострого холециститу (ГХ) оперовані $319(58,1 \%)$ пацієнтів, хронічного калькульозного холециститу (ХКХ) - 230 (41,9\%). Із 319 хворих із ГХ у 278 (87,4\%) були деструктивні форми. Інтраопераційні параметри, інтенсивність післяопераційного болю та міру відновлення в цілому, а також задоволеність пацієнтів під час спостереження проспективно зафіксовані у дослідженні з метою оцінки можливості та безпечності процедури.

Результати. Всі операції завершені лапароскопічно, у жодному спостереженні не виникло необхідності переходити 3 субарахноїдальної анестезії на загальну. Інтенсивність болю протягом 4 год після операції становила 1,6 $\pm 1,1$ (діапазон 0 - 5), через 8 год - 1,2 \pm 0,9 (діапазон 0 - 6), через 24 год - 1,02 \pm 0,7 (діапазон 0-5). Всі пацієнти виписані через 1 - 7 днів. Висновки. ЛХЕ 3 пневмоперитонеумом $\mathrm{CO}_{2}$ може бути успішно та безпечно виконана із застосуванням субарахноїдальної анестезії на спонтанному диханні. Крім того, спинальна анестезія пов'язана з мінімальним післяопераційним болем і принаймні однаковою мірою відновлення, як у разі використання загального знеболювання.

Ключові слова: субарахноїдальна анестезія; пневмоперитонеум $\mathrm{CO}_{2}$; лапароскопічна холецистектомія

\section{Abstract}

Objective. To analyze the results of application of subarachnoidal anesthesia while spontaneous respiration during performance of laparoscopic cholecystectomy (LCHE) for improvement of the regional anesthesia, while doing operations on abdominal organs. Materials and methods. In 549 patients, put to Class I-III in accordance to classification of American Society of Anesthesiology (ASA), ageing from 25 to 82 yrs and at average (48.9 \pm 13.1 ) yrs old, LCHE was performed with pneumoperitoneum, which was established, using intraabdominal blowing with $\mathrm{CO}_{2}$ and subarachnoidal anesthesia on spontaneous respiration. For an acute cholecystitis 319 (58.1\%) patients were operated and for chronic calculous cholecystitis - 230 (41.9\%). Of 319 patients, suffering an acute cholecystitis, 278 (87.4\%) have had destructive forms. Intraoperative parameters, intensity of postoperative pain and the restoration measure in total, as well as the patients' satisfaction measuring, were registered while prospective observation performance with objective to investigate the procedure's safety and possibilities.

Results. All the operations were finished laparoscopically, in no one observation conversion to subarachnoid anesthesia into general one was needed. The pain intensity during $4 \mathrm{~h}$ after the operation have constituted $1.6 \pm 1.1$ (diapason $0-5$ ), in $8 \mathrm{~h}-$ $1.2 \pm 0.9$ (diapason $0-6$ ), in $24 \mathrm{~h}-1.02 \pm 0.7$ (diapason $0-5$ ). All the patients were discharged in $1-7$ days.

Conclusion. LCHE with $\mathrm{CO}_{2}$ pneumoperitoneum may be performed successfully and securely, using subarachnoidal anesthesia on spontaneous respiration. Besides this, spinal anesthesia is connected with minimal postoperative pain and, at least with similar measure of restoration, as it occurs while application of general anesthesia.

Keywords: subarachnoidal anesthesia; $\mathrm{CO}_{2}$ pneumoperitoneum; laparoscopic cholecystectomy.

Застосування лапароскопічної хірургії надзвичайно розширилось протягом останніх років, що привело до зменшення захворюваності та скорочення термінів перебування пацієнтів у лікарні порівняно з відкритою опе- рацією. Разом з тим анестезія у таких хворих залишається практично незмінною. У більшості пацієнтів лапароскопічні операції зазвичай виконують під загальною анестезією, за винятком тих, які мають протипоказання до загаль- 
ного знеболення. Останнім часом хірургічні втручання на органах черевної порожнини дедалі частіше виконують із застосуванням регіонарних методів знеболення. $€$ кілька досліджень, в яких піддано сумніву широко розповсюджене переконання, що загальна анестезія - це найкращий анестезіологічний метод для лапароскопічної хірургії [1]. Однак значна кількість анестезіологів та хірургів доволі скептично ставиться до рутинного використання субарахноїдальної анестезії при лапароскопічних методах оперативного лікування в хірургічній практиці. Особливо це стосується лапароскопічних хірургічних втручань на органах черевної порожнини, зокрема, ЛХЕ. Більш за все авторів бентежить накладення карбоксиперитонеуму та пов'язані з цим можливі порушення вентиляції легенів.

Повідомлення про субарахноїдальну анестезію при лапароскопічних втручаннях на органах черевної порожнини поодинокі і базуються на невеликій кількості спостережень $[2,3]$.

Відзначено, що регіонарна анестезія забезпечує стабільну сегментарну анестезію, регіонарну міорелаксацію, надає можливість відмовитись від міорелаксантів і наркотиків та від проведення штучної вентиляції легенів, значно знижує ймовірність таких ускладнень, як нудота та блювання [4].

Мета дослідження: проаналізувати результати застосування субарахноїдальної анестезії на спонтанному диханні при виконанні ЛХЕ для удосконалення методу регіонарної анестезії при операціях на органах черевної порожнини.

\section{Матеріали і методи дослідження}

ЛХЕ виконана у 549 хворих віком від 25 до 82 років, середній вік - $(48,9 \pm 13,1)$ року, жінок було 374 (68,1\%), чоловіків - 175 (31,9\%). Індекс маси тіла коливався в межах 21,6 - 32,3 кг $/ \mathrm{M}^{2}$, у середньому становив $(24,2 \pm 6,7)$ кг $/ \mathrm{M}^{2} .3 \mathrm{a}$ класифікацією ASA до I класу віднесені 86 (15,7\%) хворих, до II класу - 341 (62,1\%), до III класу - 122 (22,2\%). Супутні захворювання діагностовані у 194 (35,3\%) хворих: артеріальна гіпертензія - у 49 (8,9\%), ішемічна хвороба серця у 63 (11,5\%), хронічна обструктивна хвороба легенів - у 8 (1,5\%), цукровий діабет - у 32 (5,8\%), інші - у 12 (2,2\%).

У всіх хворих застосовано метод субарахноїдальної анестезії на спонтанному диханні. Всі пацієнти обстежені в перед- та післяопераційному періодах згідно з наявними стандартами і протоколами, які включали уніфіковані лабораторні та інструментальні методи дослідження.

Премедикацію виконували в хірургічному відділенні за 30 - 40 хв до переведення хворого до операційної. у склад дом'язевої премедикації входили: дексалгін 50 мг, дексаметазон 4 - 8 мг, нефопам 20 мг.

В операційній після укладання хворого на операційний стіл внутрішньовенно вводили 1000 мг інфулгану та

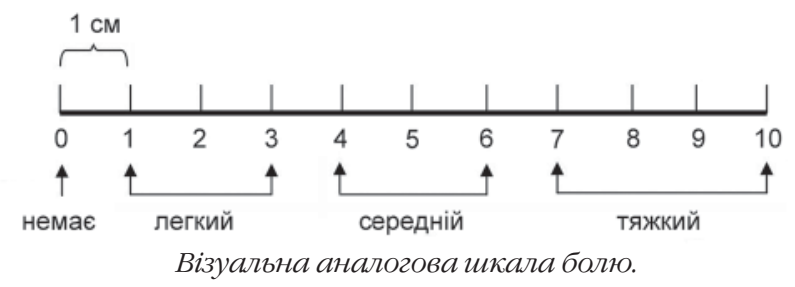

починали інфузію кристалоїдів. Премедикацію доповнювали довенним введенням 5 мг сібазону і 50 мкг фентанілу. Виконували пункцію субарахноїдального простору на рівні $\mathrm{L}_{3}-\mathrm{L}_{4}$ в положенні пацієнта лежачи на правому боці з опущеним головним кінцем під кутом 5 градусів під контролем кутоміра, вводили 0,5\% гіпербаричний розчин лонгокаїну в дозі 16 - 20 мг та 30 мкг бупренорфіну. Експозиція на правому боці після введення лонгокаіну тривала 3 хв. Гіпотонію, яка виникала внаслідок високої спінальної анестезіі, коригували розчином адреналіну (0,2 мл в 20 мл фізіологічного розчину) фракційно за допомогою інфузомату. Швидкість введення коригували відповідно до гемодинамічних показників: артеріального тиску (АТ) та пульсу.

Після виконання пункції субарахноїдального простору та укладання хворого на спину в горизонтальному положенні справа на шиї виконували блокаду діафрагмального нерва, який знаходиться у фасціальному ложі між ключичною ніжкою груднинно-ключично-соскоподібного м'яза шиї і передньою порцією драбинчастого м'яза. Ін'єкцію виконували внутрішньом'язово голкою, зігнутою під кутом $45^{\circ}$, яку вводили перпендикулярно до шкіри до відчуття провалу з наступним паралельним м'язу iï просуванням по фасціальному простору та введенням 10 мл 0,8\% лідокаїну. Аналгоседацію перед накладанням штучного пневмоперитонеуму з використанням $\mathrm{CO}_{2}$ доповнювали внутрішньовенним введенням 10 мг кетаміну і 50 мкг фентанілу.

Після введення газу та лапароскопа в черевну порожнину відразу ж через другий порт під мечоподібним відростком діафрагмальну поверхню обприскували 3\% розчином лідокаїну в дозі 600 мг (20 мл).

Спонтанне дихання повітрям, збагаченим киснем, з потоком 3 - 4 л/хв контролювали даними пульсоксиметрії $\left(\mathrm{SpO}_{2}\right)$. За допомогою монітора всім пацієнтам реєстрували такі параметри: електрокадіограму, АТ систолічний та діастолічний, частоту пульса (ЧП), $\mathrm{SpO}_{2}$, частоту дихання (ЧД). Параметри вимірювали на трьох етапах: 1-й етап до анестезії та введення $\mathrm{CO}_{2}$ в черевну порожнину; 2-й під час операції; 3-й - після закінчення введення $\mathrm{CO}_{2}$ та зняття пневмоперитонеуму.

Інтенсивність болю після операції визначали за допомогою стандартної візуальної аналогової шкали, запропонованої J. J. Bonica у 1990 р., довжиною 10 см, на якій хворий самостійно відмічав рівень болю через 4, 8 та 24 год після операції (див. рисунок).

Статистичне опрацювання даних здійснювали методом математичної статистики з використанням статистичного програмного пакета «Біостатистика». Визначали середнє арифметичне варіаційного ряду (M) та середнє квадратичне відхилення ( \pm ), відмінності оцінювали за допомогою критерію Ст’юдента при 95\% достовірності (p < 0,05).

\section{Результати}

3 приводу ГХ оперовані 319 (58,1\%) хворих, ХКХ - 230 (41,9\%). Із 319 хворих, оперованих $з$ приводу ГХ (безкам'яний ГХ був у 42, калькульозний - у 277), 278 (87,4\%) мали деструктивні форми. Середня тривалість операцій склала $(49,8 \pm 25,8)$ хв (мінімальна - 24 хв, максимальна - 115 
хв, медіана - 37 хв). У всіх хворих операції завершені лапароскопічно, в жодному спостереженні не виникло необхідності в переході на загальну анестезію.

Відомо, що підвищення внутрішньочеревного тиску під час лапароскопічних операцій створює передумови для виникнення шлунково-стравохідної регургітації 3 подальшою аспірацією шлункового кислого вмісту. Нами не зареєстровано у жодного пацієнта інтраопераційного блювання на відміну від інших авторів [5].

Під час виконання оперативних втручань у хворих систолічний АТ на 1-му етапі дослідження становив 18,0 кПа (134,8 мм рт. ст.). На 2-му етапі він знизився до 14,6 кПа (109,4 мм рт. ст.), в середньому на 18,8\%. На 3-му етапі АТ підвищився до 16,6 кПа (124,6 мм рт. ст.), залишаючись на 7,8\% нижчим, ніж на $1-$ му етапі $(\mathrm{p}<0,05)$. На $1-$ му етапі дослідження Чд становила 14,5 за 1 хв. На 2-му етапі ЧД помітно підвищилась - до 20,1 за 1 хв, в середньому на 38,6\%. Після закінчення введення $\mathrm{CO}_{2}$ та зняття пневмоперитонеуму ЧД становила 18,9 за 1 хв, залишаючись в середньому на 30,4\% більшою, ніж на 1-му етапі дослідження ( $<<0,05)$. Показник $\mathrm{SpO}_{2}$ залишався достатнім упродовж всіх етапів дослідження: 94,7; 95,7; 96,2\% відповідно. ЧП збільшувалась у період від 14 до 27 хв, потім поступово поверталася до норми: 1 -й етап - 81,2 за 1 хв, 2-й - 79,4 за 1 хв, 3-й - 76,5 за 1 хв. Після виконаних лапароскопічних втручань ніхто з пацієнтів не помер. На відміну від пацієнтів, яким застосовували загальну анестезію із штучною вентиляцією легенів, пацієнтів після застосування субарахноїдальної анестезії одразу ж після операції переводили до профільного відділення.

Після операції ці пацієнти потребували значно меншої кількості аналгетиків, особливо в 1-шу добу. Тривалий час після переводу з операційної (3 - 4 год) аналгетики взагалі не знадобилися жодному з хворих. У післяопераційному періоді опіоїди не застосовували. Інтенсивність болю протягом 4 год після операції становила 1,6 $\pm 1,1$ (діапазон 0-5), через 8 год - 1,2 0,9 (діапазон 0-6), через 24 год - 1,02 \pm 0,7 (діапазон 0-5). Пити рідину пацієнти починали через 2 год після операції, ентеральне харчування - через 4 год, активізація пацієнтів (ходіння по палаті) була можлива через 5 год. Після операцій під субарахноїдальною анестезією у поодиноких хворих виникла нудота. Всі пацієнти виписані через 1 - 7 днів.

\section{Обговорення}

Багато авторів наголошують на небезпеці проведення лапароскопічних маніпуляцій і операцій на тлі спонтанного дихання, оскільки накладення пневмоперитонеуму обмежує рухливість діафрагми, внаслідок чого знижується розтяжність легеневої тканини, виникають ателектази ділянок легенів, зменшується їх функціональна залишкова ємність, з'являються і прогресують вентиляційно-перфузійні порушення, розвиваються гіповентиляція, гіперкапнія і дихальний ацидоз. Все це змушує респіраторний апарат пацієнта до значних зусиль для усунення небажаних і небезпечних для життя станів, що виникають та можуть призвести до декомпенсації і смерті в інтра- та післяопераційному періодах. Саме тому у разі проведення лапароскопічних процедур виникає необхідність в інтубації трахеї. Накладення пневмоперитонеуму сприяє підвищенню периферичного судинного опору через стискання ззовні артеріол, зокрема, спланхнічного і ниркового басейнів. Поряд із згаданими факторами певним чином впливають на гемодинаміку гіпоксемія, гіперкапнія, дихальний ацидоз. Спонтанне дихання в умовах напруженого пневмоперитонеуму, що забезпечується нагнітанням $\mathrm{CO}_{2}$ в черевну порожнину, може здатися неефективним [3].

Проведені в останнє десятиліття дослідження показали можливість виконання ЛХЕ під спинномозковою анестезією [4, 6]. У 2009 р. R. Sinha і співавтори опублікували ретроспективний огляд 3492 ЛХЕ під спинномозковою анестезією і переконливо довели, що у хворих зменшувались частота нудоти та блювання і застосування внутрішньовенних аналгетиків для усунення болю. Крім того, розслаблення м'язів живота не було проблематичним. Біль у плечах і шиї спостерігали у 12,3\% пацієнтів, а перейти на загальну анестезію довелось у 0,5\% хворих [5].

Таким чином, регіонарна анестезія має переваги перед загальною анестезією за позитивним впливом на хірургічну стрес-відповідь, інтенсивністю післяопераційного болю, пластичністю нервової системи, системою гемостазу, частотою ускладнень в цілому $[1,4,6]$. Показник задоволеності пацієнта вище, якщо з анестезією пов'язано менше побічних ефектів після операції, таких як післяопераційний біль, запаморочення і головний біль, нудота і блювання. 3 огляду на позитивні характеристики субарахноїдальної анестезії та подальший розвиток техніки лапароскопічних операцій можна припустити, що в найближчому майбутньому регіонарна анестезія дозволить ширше використовувати лапароскопічні операції в хірургії через швидке відновлення життєво важливих функцій організму. Завдяки впровадженню регіонарної анестезії в КЗОЗ «Обласна клінічна лікарня - центр екстреної медичної допомоги та медицини катастроф» метод субарахноїдальної анестезії на спонтанному диханні за останні роки став основним при ЛХЕ.

\section{Висновки}

1. Субарахноїдальна анестезія при ЛХЕ значно полегшує перебіг інтра- і післяопераційного періоду завдяки більш надійному усуненню болю та «синдрому діафрагмального нерва».

2. Після застосування лонгокаїну та лідокаїну виникає значно менше негативних побічних ефектів у порівнянні з відповідним введенням опіоїдних аналгетиків.

3. Незважаючи на явні переваги регіонарної анестезіі, необхідно проведення подальших досліджень, спрямованих на об'єктивну аргументацію методу вибору знеболювання лапароскопічних операцій на органах черевної порожнини та заочеревинного простору.

\section{References}

1. Vretzakis G, Bareka M, Aretha D, Karanikolas M. Regional anesthesia for laparoscopic surgery: a narrative review. Journal of Anesthesia. 2014; 28(3):429-46. doi: 10.1007/s00540-013-1736-z

2. Byshovets SM. Poiednannia subarakhnoidalnoi blokady ta terminalnoi anestezii diafrahmy dlia zneboliuvannia laparoskopichnykh operatsii. In: Zbirnik naukovikh prats spivrobitnikiv NMAPO imeni P.L.Shupyka. 2013;(22):10-4.[In Ukrainian]. 
3. Tzovaras G, Fafoulakis F, Pratsas K, Georgopoulou S, Stamatiou G, Hatzitheofilou C. Spinal vs general anesthesia for laparoscopic cholecystectomy: interim analysis of a controlled randomized trial. Arch Surg. 2008;143(5):497-501. doi: 10.1001/archsurg.143.5.497

4. Kar M, Kar JK, Debnath B. Experience of laparoscopic cholecystectomy under spinal anesthesia with low-pressure pneumoperitoneum-prospective study of 300 cases. Saudi J Gastroenterol. 2011;(17):203-7. doi: $10.4103 / 1319-3767.80385$.
5. Sinha R, Gurwara AK, Gupta SC. Laparoscopic cholecystectomy under spinal anesthesia: a study of 3492 patients. J Laparoendosc Adv Surg Tech. 2009;(19):323-7. doi: 10.1089/lap.2008.0393.

6. Liu X, Wei C, Wang Z, Wang H. Different anesthesia methods for laparoscopic cholecystectomy. Anaesthesist. 2011;(60):723-8. doi: 10.1007/ s00101-011-1863-6. 